\title{
Does Corporate Governance Affect Performance? Evidence from the Textile Sector of Pakistan
}

\author{
Kaukab Abid Azhar ${ }^{1}$ and Waqas Mehmood ${ }^{2}$ \\ ${ }^{1}$ Faculty of Management Sciences, Barrett Hodgson University, Karachi, Pakistan \\ ${ }^{2}$ Institute of Business Administration, Karachi, Pakistan
}

Correspondence should be addressed to: Kaukab Abid Azhar; Kaukab.abid@bhu.edu.pk

Received date: 04 January 2018; Accepted date: 30 May 2018; Published date: 05 July 2018

Academic Editor: Umara Noreen

Copyright @ 2018. Kaukab Abid Azhar and Waqas Mehmood. Distributed under Creative

Commons CC-BY 4.0

\begin{abstract}
This study takes evidence from Pakistan Stock Exchange's top 10 listed textile companies to investigate the relationship between corporate governance and firm performance. The relationship is investigated through three important corporate governance mechanisms (board size, board composition, and audit committee composition) and two performance measures (return on assets and net profit ratio). No direct relationship was found between any of the corporate governance variables on performance variables. The findings of this study were consistent with results from many other studies conducted in developing countries. Future studies can be conducted with some additional variables to strengthen the research model and different industries can be tested to validate the findings of the study.
\end{abstract}

Keywords: Board structure, Corporate Governance, Firm Performance

\section{Introduction}

Better governance practices play a vital role in developing and enhancing investor perception. This is the reason why firms with good governance practices are able to raise investments at a much lower cost (Agrawal et al., 1996) which impacts the overall performance of the firm. There are many studies on the basis of which we can

Cite this Article as: Kaukab Abid Azhar and Waqas Mehmood (2018)," Does Corporate Governance Affect Performance? Evidence from the Textile Sector of Pakistan", Journal of Southeast Asian Research, Vol. 2018 (2018), Article ID 859648, DOI: 10.5171/2018.859648 
distinguish good and bad governance practices. Some of the common indicators include the proportion of independent directors, the role of chairman and CEO etc. (Bebchuk et al., 2004; Mishra and Mohanty, 2004).

The area of corporate performance and corporate governance is widely debated. Empirical research has shown a close association between the two variables. Some researchers have explored the relationship with the aid of agency theory (Brown and Caylor, 2005; Gompers et al., 2003) The theory suggests that corporate governance helps in higher valuation and better performance resulting in lower agency costs (Jensen and Meckling, 1976). Gomers et al. (2003) linked higher valuation of the firm with corporate governance practices. Brown and Caylor (2005) concluded that firms with better corporate governance practices have a higher ROE (Return on Equity) and ROA (Return on Assets). On the other hand, there have been instances where no evidence is found between the two variables; hence, the earlier findings cannot be generalized universally. Investors are skeptical about the relationship between governance and performance (Azeez, 2015).

Corporate governance mechanisms are different in different countries; there is a huge difference if we compare corporate governance of developed countries and emerging countries. The difference in nature of corporate governance is because emerging markets are different from developed economies in terms of the legal environment, regulatory stages, and institutions (Millar et al., 2005). Pakistan is an emerging economy. In recent times, businesses in Pakistan have suffered from many corporate governance issues and scandals which increase the significance of conducting a study to understand various dimensions of corporate governance in Pakistan.

In developed countries, including UK, Japan, France, Germany and US, many researchers have examined the linkage between corporate governance and performance of the firm in which we have observed varied findings. Only a few studies are found in emerging economies. Studies in the context of Pakistan are also limited.

The objective of the research is to investigate and study the relationship between corporate governance practices and firm performance in the textile sector of Pakistan. The textile sector contributes to around 57\% of the total exports of Pakistan; therefore, we have chosen this sector to assess corporate governance's impact on firm performance. The three research questions are:

Does board size impact firm performance of textile firms in Pakistan?

Does board composition impact firm performance of textile firms in Pakistan?

Does the composition of the audit committee impact firm performance of textile firms in Pakistan?

If we look at the global perspective, European countries had employed corporate structure mechanisms for a long period of time whereas the developing countries are catching up with developed countries. Pakistan was late in adapting to the corporate governance mechanisms, principles, and strategies. In 2002, Securities and Exchange Commission Pakistan (SECP) finalized the code of corporate governance in Pakistan which was further improved in the year 2004. There are several issues that developing and emerging countries have to face in their initial stages of adoption of corporate code of governance. The industry requires solid evidence of linkage between firm performance and governance mechanisms.

Research related to corporate governance is quite limited with respect to Pakistan. The literature review section is therefore focused more on literature available from developed countries and neighboring countries of Pakistan due to the cultural similarities. A change of corporate structure can also lead to a change in culture; however, if the culture

Kaukab Abid Azhar and Waqas Mehmood (2018), Journal of Southeast Asian Research, DOI: $10.5171 / 2018.859648$ 
is strong and shared across the society then it overpowers the corporate structure (Gordon and Roe, 2004). In Pakistan, it becomes interesting to study corporate governance because only changes in policies by regulatory authorities may not be able to change the cultural dimensions.

Most of the previous studies on examining corporate governance have focused on board size, independent directors, the role of chairman and CEO, sub-committees (Dwivedi \& Jain, 2005). Some other studies have adopted a much more expansive approach by developing multiple metrics (Gompers et al., 2001).

A study was conducted on examining the relationship with context to the Textile industry of Pakistan. This study was conducted on the basis of data from 20072011, a lot has changed since then because of changes in the corporate governance code. The empirical analysis of the data from 2007 - 2011 of 12 listed companies showed that return on assets was affected by the board size whereas no effect was observed in case of its relationship with return on equity. The study also included the dual role of CEO and chairman; however, at present, corporate code of governance restricts the duality of role. Hence for our study, we will eliminate that variable (Akbar, 2014). Instead, we have included the composition of the audit committee in our study.

\section{Literature Review}

Previous researchers have been unable to establish a conclusive result as results have varied in different contexts especially when comparisons have been drawn between emerging and developed countries (Boubaker \& Nguyen, 2014). Very little academic work is available in the context of emerging countries such as Pakistan. This paper is focused on examining the relationship between corporate governance practices and firm performance, in the context of the textile industry of Pakistan. This section discusses some of the major studies conducted examining the relationship between firm performance and corporate governance.

In a research study by Lausten (2002), CEO turnover was linked to the corporate performance. A longitudinal study of Danish firms revealed that CEO turnover had an inverse relationship with firm performance. Several corporate governance measures were used as evidence to study the relationship. Bauer et al. (2004) analyzed the impact of good governance on firm value and stock performance. They compared the performances of poorly governed with wellgoverned companies by differentiating the two through Deminor Corporate Governance Ratings. Surprisingly, a negative association was found between performance and governance.

Bhagat and Bolton (2008) studied the linkage between stock performance and corporate governance. Contrary to the popular beliefs, they found that none of the governance measures were related to the stock performance of the firm. However, the disciplinary management turnover was related to the independence of the board and stock ownership (board members). Firms with better governance were less likely to suffer from disciplinary management takeover despite their poor performances. This study opened up new avenues for researchers to examine the different dimensions of corporate governance.

The first significant study, in context to developing economies, (to the best of the knowledge of the researcher) was conducted by Kajola (2008) in Nigeria. On the basis of panel data of 20 Nigerian companies, he found mixed results as some of the performance measures were related to better governance while some were not. Another study in Nigeria was conducted by Ehikioya (2009) in which he investigated the relationship with empirical evidence. Fiveyear data of 107 Nigerian listed companies indicated a positive relationship between firm performance and corporate governance.

Kaukab Abid Azhar and Waqas Mehmood (2018), Journal of Southeast Asian Research, DOI: $10.5171 / 2018.859648$ 
The researcher called for more research across borders to validate his findings.

The relationship under study has been extensively researched in Sri Lanka which like Pakistan is a developing economy. Heenetigala and Armstrong (2011) obtained data from 37 of the top 50 listed companies in Sri Lanka and concluded that there is a positive association between firm performance and corporate governance. Similarly, Guo and Kga (2012) examined the relationship in Sri Lanka by taking data from Colombo Stock Exchange. Data from 174 firms revealed mixed findings in which some corporate governance variables were linked to better performance while some were not. Velnampy (2013) studied corporate governance and firm performance in Sri Lanka. He analyzed data from 28 manufacturing companies over the period of five years which revealed that no association was present in performance measures and governance.

Much of the corporate culture of Pakistan is similar to that of India; therefore, it is important to look at some significant studies in India on this topic. Mishra (2014) conducted a study on investigating the relationship between corporate governance and financial performance. Findings were based on data from 141 listed companies on Mumbai Stock Exchange. Mishra concluded that corporate governance has a positive relationship with a firm's financial performance. Arora (2016) studied the relationship with data from 20 important industries of India. Performance improved with the increase in the board size; however, ROE and profitability were not impacted by other corporate governance measures. Similar findings were observed in another study conducted in India by Bansal and Sharma (2016). Panel data of 235 firms showed that CEO-chairman duality and board size had a positive association with performance; however, audit committee composition did not have any significant association with performance.

Very little academic work has been conducted in Pakistan related to corporate governance. Ibrahim et al. (2010) examined the relationship in the Pharmaceutical sector of Pakistan. Findings showed that ROE was impacted by corporate governance whereas no significant relationship was found between performance and ROA. Similar results were found in a case study conducted by Dar et al. (2011) in which Oil and Gas companies were studied. Some performance measures had a negative effect of CEO duality and audit committee composition. Another significant study was conducted by Yasser et al. (2011) in which the relationship was examined by taking data of KSE 30 (Karachi Stock Exchange) companies. They found no significant relationship between corporate governance mechanism and performance variables. Our study aims to add to the existing literature by studying the relationship in context to the textile industry of Pakistan. 
Table 1: Summary of Relevant Studies

\begin{tabular}{|l|l|l|}
\hline Author (s) & Country & $\begin{array}{l}\text { Relationship between corporate } \\
\text { governance and firm performance }\end{array}$ \\
\hline Kang and Shivdasani (1995) & Japan & No significant relationship \\
\hline Brown and Caylor (2004) & Multiple & Positive relationship \\
\hline Bauer et al. (2004) & European & Negative relationship \\
\hline Bhagat and Bolton (2008) & Multiple & No significant relationship \\
\hline Kajola (2008) & Nigeria & Mixed findings \\
\hline Ehikioya (2009) & Nigeria & Positive relationship \\
\hline Ibrahim et al. (2010) & Pakistan & Mixed findings \\
\hline Heenitagala and Armstrong (2011) & Sri Lanka & Positive relationship \\
\hline Dar et al. (2011) & Pakistan & Mixed findings \\
\hline Yasser et al. (2011) & Pakistan & No significant relationship \\
\hline Guo and Kga (2012) & Sri Lanka & Mixed findings \\
\hline Velnampy (2013) & Sri Lanka & No significant relationship \\
\hline Achchuthan and Rajendran (2013) & Sri Lanka & No significant relationship \\
\hline Mishra (2014) & India & Positive relationship \\
\hline Azeez (2015) & Sri Lanka & Positive relationship \\
\hline Arora (2016) & India & Mixed findings \\
\hline Bansal and Sharma (2016) & India & Mixed findings \\
\hline Buallay et al. (2017) & Saudi Arabia & No significant relationship \\
\hline Maranho and Leal (2018) & Latin America & Positive relationship \\
\hline
\end{tabular}

\section{Firm Performance}

Managerial performance, traditionally, is measured on a firm's financial performance (Jr, 1991). Many accounting ratios, such as return on equity, return on assets, return on sales etc., can be used to assess a firm's performance. The stock price of a firm is positively correlated with ROA, theoretically (Selling and Stickney, 1989). Since the study is based on listed firms of PSX, ROA is considered as a better measure as the increase in ROA will imply a higher return for shareholders. The other performance variable used in this study is related to the profitability of the firm, Net Profit Ratio. Board Size

It is always a difficult task to find an ideal size of the board (Ning et al., 2015); however, some studies have suggested that, ideally, a board should consist of members between 7 10 (Jensen, 1993; Lipton and Lorsch, 1992). Large board sizes are susceptible to blaming others for performance failures and relying on others for risky decisions (Hermalin and
Weisbach, 2001). On the other hand, smaller board size will lead to a lack of diversity of opinions and issues of staffing other committees. In Pakistan, board size is not fixed as it may vary depending on the size of the company; however, there should be a minimum of five directors ("Code of Corporate Governance 2012 Amended July 2014 - SECP," 2017). Previous studies have established that firm performance and board size have a strong positive correlation (Dalton et al., 1999).

\section{Board Composition}

It relates to the composition of the board and the presence of independent directors. Board composition, with a majority of independent directors, is more inclined to respond to the poor performance of CEO (Weisbach, 1988), less probability of fraud (Uzun et al., 2004), and far greater monitoring management (Bhagat and Black, 1998). Pakistan's corporate code of governance states that there should be one independent director (at least) on the board. It also states that $1 / 3^{\text {rd }}$

Kaukab Abid Azhar and Waqas Mehmood (2018), Journal of Southeast Asian Research, DOI: $10.5171 / 2018.859648$ 
members on the board should be independent directors (preferably). Studies have indicated a positive / relationship between performance and the number of independent directors (Byrd and Hickman, 1992).

\section{The composition of Audit Committee}

It relates to the presence in audit committee of independent directors. Corporate governance code of Pakistan states that there should be at least one independent director in the audit committee. For our study, we have included the number of non-executive directors as well in the composition of the audit committee. It also states it is preferred that the independent director is the chairman of the audit committee. Investors are more inclined to trust those companies in which the proportion of independent directors is higher in comparison (Uzun et al., 2004).

\section{Hypothesis}

$\mathrm{H}_{1}$ : Board size has a significant impact on firm performance

\section{Model Specification}

Below is the model used for this study:

$\mathrm{Y}=\beta_{0}+\beta$ (Corporate Governance mechanisms) $+\mathrm{e}$

Where,

$\mathrm{Y}$ is the dependent variable i.e. firm performance i) ROA ii) Net Profit Ratio

$\beta_{0}$ is constant

$\mathrm{e}$ is the error term

If we expand the model with relevance to our study, we will get:

Firm performance $=\beta_{0}+\beta 1$ Boardsize $+\beta 2$ Boardcomposition $+\beta 3$ Auditcommittee $+e$

\section{Variable Description}

Dependent Variable:

Return on Assets $=$ Net Income $/$ Total Assets

Net Profit Ratio $=$ Profit after Interest $/$ Total Sales

Kaukab Abid Azhar and Waqas Mehmood (2018), Journal of Southeast Asian Research, DOI: $10.5171 / 2018.859648$
$\mathrm{H}_{2}$ : Board composition has a significant impact on firm performance

$\mathrm{H}_{3}$ : Audit committee composition has a significant impact on firm performance

\section{Methodology}

Secondary data were collected from audited financial reports of top 10 listed companies in the textile sector. The top 10 companies (Azgard Nine, Nishat Mills, Gul Ahmed, Nishat Chunian, and Artistic Denim Mills, Crescent Textiles, Kohinoor Textile Mills, Sapphire Textiles, Redco Textiles and Masood Textiles) were selected on the basis of market capitalization after reviewing annual reports of listed textile firms. A regression model was used to assess the relationship between the performance variable (ROA and Net profit ratio) and corporate governance mechanism (audit committee, board composition, and board size). The data for the study were derived from audited financial statements from company annual statements of 2012 2016. 
Independent Variables:

Board size $=$ Number of members on the board

Board Composition $=$ Number of N.E.D. (Non-Executive Directors) and independent directors on the board

Audit Committee $=$ Number of independent directors and members of the audit committee outside the directors

\section{Results and Discussion}

Descriptive Statistics

All the variables of the study are represented in Table 1. It shows that the average board size of the top 10 textile listed companies is 7 board members. The mean of board composition represents that on an average there are 4 members that are either nonexecutive directors or independent directors, present in the board. The majority (87\%) of the audit committees is composed of members other than executive directors and chairman. The mean return on assets during that period was $3 \%$. The mean net profit ratio during that period was $2 \%$.

Table 1.1: Descriptive Statistics

\begin{tabular}{|l|c|c|c|c|c|}
\hline & Board Size & $\begin{array}{l}\text { Board } \\
\text { Composition }\end{array}$ & $\begin{array}{l}\text { Audit } \\
\text { Committee }\end{array}$ & ROA & $\begin{array}{l}\text { Net Profit } \\
\text { Ratio }\end{array}$ \\
\hline Mean & 7.20 & 4.44 & 0.87 & 0.03 & 0.02 \\
\hline Median & 7.00 & 4.00 & 1.00 & 0.04 & 0.04 \\
\hline Maximum & 9.00 & 6.00 & 1.00 & 0.18 & 0.18 \\
\hline Minimum & 7.00 & 3.00 & 0.33 & -0.18 & -0.53 \\
\hline Std. Dev. & 0.57 & 1.11 & 0.19 & 0.07 & 0.10 \\
\hline Skewness & 2.65 & 0.33 & -1.30 & -0.80 & -3.18 \\
\hline Kurtosis & 8.37 & 1.74 & 3.80 & 5.50 & 16.37 \\
\hline Jarque-Bera & 118.78 & 4.20 & 15.46 & 18.52 & 457.07 \\
\hline Probability & 0.00 & 0.12 & 0.00 & 0.00 & 0.00 \\
\hline Sum & 360.00 & 222.00 & 43.68 & 1.84 & 1.31 \\
\hline Sum sq. Dev. & 16.00 & 60.32 & 1.75 & 0.22 & 0.56 \\
\hline
\end{tabular}

Kaukab Abid Azhar and Waqas Mehmood (2018), Journal of Southeast Asian Research, 


\section{Correlations and Regression}

Table 1.2 represents the correlation of firm performance variables with other independent variables. The table shows that the only significant correlation of Return on Assets is with Board Composition which has a moderate to strong positive correlation. The correlation between the other two variables (Board Size and Audit Committee) is statistically insignificant. Similarly, net profit ratio has a significant relationship with Board composition while its relationship with board size and audit committee is statistically insignificant.

Table 1.2: Correlation

\begin{tabular}{|c|c|c|c|c|c|}
\hline & Board Size & $\begin{array}{l}\text { Board } \\
\text { Composition }\end{array}$ & $\begin{array}{l}\text { Audit } \\
\text { Committee }\end{array}$ & ROA & $\begin{array}{l}\text { Net Profit } \\
\text { Ratio }\end{array}$ \\
\hline Board Size & 1 & & & & \\
\hline $\begin{array}{l}\text { Board } \\
\text { Composition }\end{array}$ & $\begin{array}{l}0.05 \\
0.72\end{array}$ & 1 & & & \\
\hline Audit Committee & $\begin{array}{l}-0.32 \\
0.02\end{array}$ & $\begin{array}{l}0.18 \\
0.19\end{array}$ & 1 & & \\
\hline ROA & $\begin{array}{l}0.05 \\
0.70\end{array}$ & $\begin{array}{l}0.38 \\
0.00\end{array}$ & $\begin{array}{l}-0.09 \\
0.54\end{array}$ & 1 & \\
\hline Net Profit Ratio & $\begin{array}{l}-0.03 \\
0.82\end{array}$ & $\begin{array}{l}0.32 \\
0.02\end{array}$ & $\begin{array}{l}-0.09 \\
0.51\end{array}$ & $\begin{array}{l}0.90 \\
0.00\end{array}$ & 1 \\
\hline
\end{tabular}

Table 1.3 explains the regression after applying the model for firm performance indicator ROA. Correlation of return on assets with the model is explained by $\mathrm{R}$ (Standardized coefficient of correlation) = 0.07 which explains the relationship of the combined variables with the dependent variable. The coefficient of determination $\left(R^{2}\right)$ explains 0.70 or $70 \%$ variance in return on assets with a change in combined independent variables; whereas, the overall model is significant $(F=7.17, \operatorname{Sig}=0.00)$. Relationship between board size and return on assets is insignificant as $\mathrm{t}=1.70$ and $\mathrm{Sig}=$ 0.09. Relationship between board composition and return on assets is insignificant as $t=-1.32$ and Sig $=0.19$. The relationship between the audit committee and return on assets is insignificant as $\mathrm{t}=$ .02 and $\mathrm{Sig}=0.76$. 
Table 1.3: Regression (Return on Assets)

\begin{tabular}{|c|c|c|c|c|}
\hline \multicolumn{5}{|c|}{$\begin{array}{l}\text { Dependent Variable: ROA } \\
\text { Method: Panel Least Squares } \\
\text { Date: } 12 / 22 / 17 \text { Time: } 10: 26 \\
\text { Sample: } 20122016 \\
\text { Periods included: } 5 \\
\text { Cross-sections included: } 10 \\
\text { Total panel (balanced) observations: } 50\end{array}$} \\
\hline Variable & Coefficient & Std. Error & t-Statistic & Prob. \\
\hline $\begin{array}{c}\text { C } \\
\text { BOARDSIZE } \\
\text { BOARDCOMPOSITION } \\
\text { AUDITCOMMITTEE }\end{array}$ & $\begin{array}{r}-0.077405 \\
0.027879 \\
-0.023733 \\
0.021711\end{array}$ & $\begin{array}{l}0.115696 \\
0.016378 \\
0.017908 \\
0.070552\end{array}$ & $\begin{array}{r}-0.669036 \\
1.702246 \\
-1.325256 \\
0.307731\end{array}$ & $\begin{array}{l}0.5076 \\
0.0971 \\
0.1932 \\
0.7600\end{array}$ \\
\hline \multicolumn{5}{|c|}{ Effects Specification } \\
\hline \multicolumn{5}{|c|}{ Cross-section fixed (dummy variables) } \\
\hline $\begin{array}{l}\text { R-squared } \\
\text { Adjusted R-squared } \\
\text { S.E. of regression } \\
\text { Sum squared resid } \\
\text { Log likelihood } \\
\text { F-statistic } \\
\text { Prob(F-statistic) }\end{array}$ & $\begin{array}{l}0.699310 \\
0.601789 \\
0.042876 \\
0.068019 \\
94.05290 \\
7.170873 \\
0.000002\end{array}$ & $\begin{array}{l}\text { Mean depen } \\
\text { S.D. depende } \\
\text { Akaike info cr } \\
\text { Schwarz crite } \\
\text { Hannan-Quir } \\
\text { Durbin-Wats }\end{array}$ & $\begin{array}{l}\text { ent var } \\
\text { nt var } \\
\text { terion } \\
\text { ion } \\
\text { n criter. } \\
\text { n stat }\end{array}$ & $\begin{array}{r}0.036916 \\
0.067945 \\
-3.242116 \\
-2.744990 \\
-3.052808 \\
2.295666\end{array}$ \\
\hline
\end{tabular}

Table 1.4 explains the regression after applying the model for firm performance indicator net profit ratio. Correlation of net profit ratio with the model is explained by $\mathrm{R}$ (Standardized coefficient of correlation) = 0.13 which explains the relationship of the combined variables with the dependent variable. The coefficient of determination $\left(\mathrm{R}^{2}\right)$ explains 0.59 or $59 \%$ variance in net profit ratio with a change in combined independent variables; whereas, the overall model is insignificant $(\mathrm{F}=4.54, \mathrm{Sig}=0.00)$. The relationship between board size and net profit ratio is insignificant as $\mathrm{t}=1.03$ and Sig $=0.30$. Relationship between board composition and net profit ratio is insignificant as $\mathrm{t}=-0.63$ and sig $=0.52$. The relationship between the audit committee and net profit ratio is insignificant as $\mathrm{t}=0.27$ and Sig $=0.78$.

Kaukab Abid Azhar and Waqas Mehmood (2018), Journal of Southeast Asian Research, DOI: $10.5171 / 2018.859648$ 
Table 1.4: Regression (Net Profit Ratio)

\begin{tabular}{|c|c|c|c|c|}
\hline \multicolumn{5}{|c|}{$\begin{array}{l}\text { Dependent Variable: NETPROFITRATIO } \\
\text { Method: Panel Least Squares } \\
\text { Date: } 12 / 22 / 17 \text { Time: 10:27 } \\
\text { Sample: } 20122016 \\
\text { Periods included: } 5 \\
\text { Cross-sections included: } 10 \\
\text { Total panel (balanced) observations: } 50\end{array}$} \\
\hline Variable & Coefficient & Std. Error & t-Statistic & Prob. \\
\hline $\begin{array}{c}\text { C } \\
\text { BOARDSIZE } \\
\text { BOARDCOMPOSITION } \\
\text { AUDITCOMMITTEE }\end{array}$ & $\begin{array}{r}-0.135837 \\
0.031102 \\
-0.021056 \\
0.036161\end{array}$ & $\begin{array}{l}0.212875 \\
0.030134 \\
0.032950 \\
0.129811\end{array}$ & $\begin{array}{r}-0.638109 \\
1.032124 \\
-0.639023 \\
0.278567\end{array}$ & $\begin{array}{l}0.5273 \\
0.3087 \\
0.5267 \\
0.7821\end{array}$ \\
\hline \multicolumn{5}{|c|}{ Effects Specification } \\
\hline \multicolumn{5}{|c|}{ Cross-section fixed (dummy variables) } \\
\hline $\begin{array}{l}\text { R-squared } \\
\text { Adjusted R-squared } \\
\text { S.E. of regression } \\
\text { Sum squared resid } \\
\text { Log likelihood } \\
\text { F-statistic } \\
\text { Prob(F-statistic) }\end{array}$ & $\begin{array}{l}0.595576 \\
0.464411 \\
0.078889 \\
0.230270 \\
63.56617 \\
4.540670 \\
0.000181\end{array}$ & $\begin{array}{l}\text { Mean depen } \\
\text { S.D. depend } \\
\text { Akaike info o } \\
\text { Schwarz crit } \\
\text { Hannan-Qui } \\
\text { Durbin-Wats }\end{array}$ & $\begin{array}{l}\text { ent var } \\
\text { nt var } \\
\text { terion } \\
\text { ion } \\
\text { n criter. } \\
\text { in stat }\end{array}$ & $\begin{array}{r}0.026200 \\
0.107796 \\
-2.022647 \\
-1.525521 \\
-1.833339 \\
2.473945\end{array}$ \\
\hline
\end{tabular}

\section{Findings}

There is sufficient literature on investigating the relationship under study in different contexts; however, contrasting results have emerged. In this study, we examined the relationship in the context of Pakistan's top 10 listed textile companies. Top 10 listed textile firms were selected on the basis of market capitalization and their annual reports were reviewed from a period of 2012 - 2016. Multiple regression analysis (cross sections fixed) was used to analyze the

results. Following are the major findings of the study:

1. No relationship between board size and return on assets

2. No relationship between board composition and return on assets

3. No relationship between audit committee and return on assets
4. The combined model, which has three independent variables (board size, board composition, and audit committee) and one dependent variable (return on assets), the relationship is positive and significant.

5. No relationship between board size and net profit ratio.

6. No relationship between board composition and net profit ratio.

7. No relationship between the audit committee and net profit ratio.

8. The combined model, which has three independent variables (board size, board composition, and audit committee) and one dependent variable (net profit ratio), the relationship is significant and positive.

Kaukab Abid Azhar and Waqas Mehmood (2018), Journal of Southeast Asian Research, DOI: $10.5171 / 2018.859648$ 


\section{Discussion and Conclusion}

Our results are consistent with the findings from the previous study conducted in Pakistan on PSX 30 companies (Yasser, Entebang, \& Mansor, 2015). Their study could not establish a significant relationship between any performance variables with the corporate governance measures. Another research in Pakistan investigated the firm performance of 50 listed companies by developing a CGI index (Corporate Governance Index) (Y. Javed and Iqbal, 2006). They concluded that firm performance cannot be replaced by adequate governance standards which hinted towards the same results that our study has obtained.

The results are somewhat similar to the results by Velnampy (2013), the study found that corporate governance mechanisms were not related to the performance measures of 28 manufacturing companies in Sri Lanka. Return on assets was also used as a performance measure and no effect was found on corporate governance (Velnampy, 2013). Another study in Sri Lanka showed different results in which data were collected from 174 firms for one year (2010). Board size and board composition had a significant impact on listed firms on firm performance (Guo and Kga, 2012). Another research in Sri Lanka studied the same relationship with data from 37 companies and found that there is a positive relationship between corporate governance and firm performance. (Heenetigala and Armstrong, 2011)

The findings from our study are quite similar to the study conducted in South Korea and India (Gupta and Sharma, 2014). The study did not evaluate the same performance measures that are used in our study; however, they concluded that share price and financial performance of companies was not linked to corporate governance practices. Another research in India studied data from 2008-2012 of 119 Indian companies and concluded that ROA had a negative relationship with board variables (Garg and Singh, 2017).
The area of corporate governance is gaining importance day by day. Many frauds like World Com and Enron have increased the significance of corporate governance. Developed countries have researched heavily on finding strong evidence for establishing a valid relationship between performance and governance mechanisms. Results from various countries have been differing. In developing and emerging countries, studies have shown contrasting findings. Some indicated a positive relationship while some showed no relationship. There have been studies in which even a negative relationship has been found. Our study suggests that in the textile sector of Pakistan, there is no impact of corporate governance measures on firm performance.

\section{Limitation and Future Research}

Our research is based on a small sample size. Future research can get conclusive findings by increasing the sample size. For our research, only two performance variables were used (return on assets and net profit ratio). Other studies may include other performance variables, such as ROE, to study if the same findings are applicable or not. The empirical literature suggests that most of the studies have been conducted on large scale businesses; therefore, studies on small-scale companies might reveal some interesting findings. A comparative study can also be conducted comparing findings from emerging and developed countries.

\section{References}

1. Achchuthan, S., Rajendran, K., 2013, 'Corporate Governance Practices and Firm Performance: Evidence from Sri Lanka' (SSRN Scholarly Paper No. ID 2447202). Social Science Research Network, Rochester, NY.

2. Agrawal, R., Findley, S., Greene, S., Huang, K., Jeddy, A., Lewis, W.W., Petry, M., 1996, 'Capital Productivity: Why the US Leads and Why It Matters.' McKinsey $Q, 38$.

Kaukab Abid Azhar and Waqas Mehmood (2018), Journal of Southeast Asian Research, DOI: $10.5171 / 2018.859648$ 
3. Akbar, A., 2014, 'Corporate Governance and Firm Performance: Evidence from Textile Sector of Pakistan.' J. Asian Bus. Strategy, 4, 200-207.

4. Arora, A., Sharma, C., 2016, 'Corporate governance and firm performance in developing countries: evidence from India.' Corporate Governance, 16, 420-436. https://doi.org/10.1108/CG-01-2016-0018

5. Azeez, A., 2015, 'Corporate Governance and Firm Performance: Evidence from Sri Lanka.'

https://doi.org/10.15640/jfbm.v3n1a16

6. Bauer, R., Guenster, N., Otten, R., 2004, 'Empirical evidence on corporate governance in Europe: The effect on stock returns, firm value and performance.' J Asset Management, 5 , 91-104. https://doi.org/10.1057/palgrave.jam.2240 131

7. Bansal, N., Sharma, A.K., 2016, 'Audit Committee, Corporate Governance and Firm Performance: Empirical Evidence from India.' International Journal of Economics and Finance, $8, \quad 103$. https://doi.org/10.5539/ijef.v8n3p103

8. Bebchuk, L.A., Cohen, A., Ferrell, A., 2004, 'What Matters in Corporate Governance? (SSRN Scholarly Paper No. ID 593423).' Social Science Research Network, Rochester, NY.

9. Bhagat, S., Black, B.S., 1998, 'The NonCorrelation Between Board Independence and Long-Term Firm Performance (SSRN Scholarly Paper No. ID 133808).' Social Science Research Network, Rochester, NY.

10.Bhagat, S., Bolton, B., 2008, 'Corporate governance and firm performance.' Journal of Corporate Finance, Special Issue: Contractual Corporate Governance, 14, 257-273. https://doi.org/10.1016/j.jcorpfin.2008.03.0 $\underline{06}$
11.Brown, L., Caylor, M., 2005, 'Corporate Governance and Firm Valuation (SSRN Scholarly Paper No. ID 754484).' Social Science Research Network, Rochester, NY.

12.Buallay, A., Hamdan, A., Zureigat, Q., 2017, 'Corporate Governance and Firm Performance: Evidence from Saudi Arabia.' Australasian Accounting, Business, and Finance Journal, 11, 78-98. https://doi.org/10.14453/aabfj.v11i1.6

13.Byrd, J.W., Hickman, K.A., 1992, 'Do outside directors monitor managers? ${ }^{*} 1$ : Evidence from tender offer bids.' J. Finance. Econ., 32, 195-221.

14.Code of Corporate Governance 2012 Amended July 2014 - SECP, 2017.

15.Dalton, D.R., Daily, C.M., Johnson, J.L., Ellstrand, A.E., 1999, 'Number of Directors and Financial Performance: A Meta-Analysis.' Acad. Manage. J., 42, 674-686. https://doi.org/10.2307/256988

16.Dar, D.L., Naseem, M.A., Niazi, D.G.S.K., Rehman, R.U., 2011, 'Corporate Governance and Firm Performance: A Case Study of Pakistan Oil and Gas Companies listed In Karachi Stock Exchange.' Global Journal of Management And Business Research, 11.

17.Ehikioya, B.I., 2009, 'Corporate governance structure and firm performance in developing economies: evidence from Nigeria.' Corporate Governance, 9, 231-243. https://doi.org/10.1108/147207009109643 $\underline{07}$

18.Garg, M.C., Singh, D., 2017, 'Corporate governance and firm performance in Indian companies.' Int. J. Indian Cult. Bus. Manag., 15, 420-444. https://doi.org/10.1504/IJICBM.2017.08762 9

19.Gompers, P., Ishii, J., Metrick, A., 2003, 'Corporate Governance and Equity Prices.' $Q$. J. Econ., 118, 107-156.

Kaukab Abid Azhar and Waqas Mehmood (2018), Journal of Southeast Asian Research, DOI: $10.5171 / 2018.859648$ 
https://doi.org/10.1162/003355303605351 62

20.Gompers, P.A., Ishii, J.L., Metrick, A., 2001, 'Corporate Governance and Equity Prices (SSRN Scholarly Paper No. ID 278920).' Social Science Research Network, Rochester, NY.

21.Gordon, J.N., Roe, M.J., 2004, 'Convergence and Persistence in Corporate Governance.' Cambridge University Press.

22.Guo, Z., Kga, U.K., 2012, 'Corporate Governance and Firm Performance of Listed Firms in Sri Lanka.' Procedia - Soc. Behav. Sci., Asia Pacific Business Innovation, and Technology Management Society, 40, 664667.

https://doi.org/10.1016/j.sbspro.2012.03.24 6

23.Gupta, P., Sharma, A.M., 2014, 'A Study of the Impact of Corporate Governance Practices on Firm Performance in Indian and South Korean Companies.' Procedia - Soc. Behav. Sci., International Conference on Trade, Markets and Sustainability (ICTMS-2013), 133, 4-11. https://doi.org/10.1016/j.sbspro.2014.04.16 3

24.Heenetigala, K., Armstrong, A., 2011, 'The Impact of Corporate Governance on Firm Performance in an Unstable Economic and Political Environment: Evidence from Sri Lanka (SSRN Scholarly Paper No. ID 1971927).' Social Science Research Network, Rochester, NY.

25.Hermalin, B.E., Weisbach, M.S., 2001, 'Boards of Directors as an Endogenously Determined Institution: A Survey of the Economic Literature (Working Paper No. 8161).' National Bureau of Economic Research. https://doi.org/10.3386/w8161

26.Ibrahim, Q., Rehman, R., Raoof, A., 2010, 'Role of corporate governance in firm performance: A comparative study of chemical and pharmaceutical sectors of Pakistan.' International Research Journal of Finance and Economics 50, 7-16.
27.Jensen, M.C., 1993, 'The Modern Industrial Revolution, Exit, and the Failure of Internal Control Systems.' J. Finance 48, 831-880. https://doi.org/10.1111/j.15406261.1993.tb04022.x

28.Jensen, M.C., Meckling, W.H., 1976, 'Theory of the firm: Managerial behavior, agency costs, and ownership structure.' J. Finance. Econ., 3, 305-360. https://doi.org/10.1016/0304405X(76)90026-X

29.Jr, R.G.E., 1991, 'The Performance Measurement Manifesto.' Routledge Publishers.

30.Kajola, S., 2008, 'Corporate Governance and Firm Performance: The Case of Nigerian Listed Firms.' European Journal of Economics, Finance and Administrative Sciences, 14.

31.Kang, J.-K., Shivdasani, A., 1995, 'Firm performance, corporate governance, and top executive turnover in Japan.' Journal of Financial Economics, 38, 29-58. https://doi.org/10.1016/0304405X(94)00807-D

32.Lausten, M., 2002, 'CEO turnover, firm performance and corporate governance: empirical evidence on Danish firms.' International Journal of Industrial Organization, 20, 391-414. https://doi.org/10.1016/S01677187(00)00083-7

33.Lipton, M., Lorsch, J.W., 1992, 'A Modest Proposal for Improved Corporate Governance.' Bus. Lawyer, 48, 59-77.

34.Maranho, F.S., Leal, R., 2018, 'Corporate governance and firm performance in Latin America: a meta-analysis.' Ac Rev Latino Admin 1, (1). https://doi.org/10.1108/ARLA04-2017-0126

35.Millar, C.C., Eldomiaty, T.I., Choi, C.J., Hilton, B., 2005, 'Corporate Governance and Institutional Transparency in Emerging Markets.' J. Bus. Ethics, 59, 163-174.

Kaukab Abid Azhar and Waqas Mehmood (2018), Journal of Southeast Asian Research, DOI: $10.5171 / 2018.859648$ 
https://doi.org/10.1007/s10551-005-34121

36.Mishra, S., Mohanty, P., 2014, 'Corporate governance as a value driver for firm performance: evidence from India.' Corporate Governance, $\quad 14, \quad 265-280$. https://doi.org/10.1108/CG-12-2012-0089

37.Ning, Y., Davidson, W.N., Wang, J., 2015, 'Does Optimal Corporate Board Size Exist? An Empirical Analysis (SSRN Scholarly Paper No. ID 2693077).' Social Science Research Network, Rochester, NY.

38.Selling, T.I., Stickney, C.P., 1989. 'The Effects of Business Environment and Strategy on a Firm's Rate of Return on Assets.' Finance. Anal. J., 45, 43-52. https://doi.org/10.2469/faj.v45.n1.43

39.Uzun, H., H. Szewczyk, S., Varma, R., 2004, 'Board Composition and Corporate Fraud.'
Finance Anal. $\quad J ., \quad 60$. https://doi.org/10.2469/faj.v60.n3.2619

40.Velnampy, T., $\quad 2013, \quad$ 'Corporate Governance and Firm Performance: A Study of Sri Lankan Manufacturing Companies.' J. Econ. Sustain. Dev., 04, 228-235.

41.Weisbach, M., 1988, 'Outside Directors and CEO Turnover.' J. Finance. Econ., 20, 431$460 . \quad$ https://doi.org/10.1016/0304405X(88)90053-0

42.Yasser, Q.R., Entebang, H.A., Mansor, S.A., 2015, 'Corporate Governance and Firm Performance in Pakistan: The Case of Karachi Stock Exchange (KSE)-30' (SSRN Scholarly Paper No. ID 2551636). Social Science Research Network, Rochester, NY.

43.Y. Javed, A., Iqbal, R., 2006, 'Corporate Governance and Firm Performance: Evidence from Karachi Stock Exchange.' Pak. Dev. Rev., 45, 947-964.

Kaukab Abid Azhar and Waqas Mehmood (2018), Journal of Southeast Asian Research, DOI: $10.5171 / 2018.859648$ 